\title{
Perlawanan Etnis Muslim Rohingya terhadap Kebijakan Diskriminatif Pemerintah Burma-Myanmar
}

\author{
Gulia Ichikaya Mitzy \\ Jurusan Ilmu Hubungan Internasional, Fakultas Ilmu Sosial dan Ilmu Politik, \\ Universitas Nasional Jakarta
}

\begin{abstract}
This research aims to provide a description that the emergence of resistances which committed by Muslim Rohingya in Burma-Myanmar is a result of discriminatory policy. Where there are differences pattern of resistance which carried out during 64 years or two periods of the government, namely Military Junta and Democratic Transition era. This research was based on cases of discrimination against Muslim Rohingya in Burma-Myanmar. Cases about discrimination which Muslim Rohingya accepted could be the basis of their resistance. Their resistance is not just physical but also tended to be subjective. The pattern differences factor is signaled caused by the change in government or an era. Besides, the majority reported news showed about their suffering, not about what have they done responding the policy or discriminatory treatment against them.
\end{abstract}

Keywords: Muslim Rohingya, resistance, discrimination

\begin{abstract}
Abstrak
Penelitian ini bertujuan untuk memberikan gambaran bahwa munculnya perlawanan yang dilakukan oleh etnis Muslim Rohingya merupakan respons terhadap menguatnya kebijakan ataupun perlakuan diskriminatif yang terjadi di Burma-Myanmar. Terdapat perbedaan pola perlawanan yang dilakukan selama rentang waktu 64 tahun atau dua periode pemerintahan, yaitu zaman Junta Militer dan Transisi Demokrasi. Penelitian ini dilatarbelakangi oleh kasus-kasus mengenai diskriminasi terhadap etnis Muslim Rohingya di Burma-Myanmar. Kasus-kasus mengenai diskriminasi yang diterima oleh etnis Muslim Rohingya disinyalir sebgai dasar perlawanan. Perlawanan tersebut tidak hanya bersifat fisik tetapi juga yang cenderung subjektif. Faktor perbedaan pola tersebut disinyalir oleh adanya perubahan zaman atau era pemerintahan.. Selain itu, tulisan ataupun pemberitaan yang ada selama ini mayoritas menunjukkan tentang penderitaan yang mereka alami, bukan apa yang telah mereka lakukan dalam merespon kebijakan atau perlakuan diskriminatif di Burma-Myanmar.
\end{abstract}

Kata kunci: Muslim Rohingya, perlawanan, diskriminasi 
Etnis Muslim Rohingya merupakan satu dari total 135 etnis minoritas yang ada di BurmaMyanmar. Adapun dari sejumah etnis minoritas tersebut, etnis Muslim Rohingya dianggap etnis yang paling teraniaya (most persecuted ethnic) menurut PBB (Perserikatan Bangsa-Bangsa). Etnis muslim Rohingya telah didiskriminasi sejak tahun 1948 ketika adanya pemisahan etnis yang dilakukan oleh Inggris. Pemisahan yang dilakukan di wilayah Rakhine tersebut memisahkan etnis Buddha Myanmar dan Muslim Rohingya. Dibawah pemerintahan militer yang menguasai Burma-Myanmar, pada tahun 1982 muncul kebijakan baru yang disebut Burma Citizenship Law (BCL) dimana warga Rohingya tidak mendapat kewarganegaraan, hak atas tanah, dan pendidikan serta pekerjaan yang layak dan cukup.

Etnis ini tidak hanya teraniaya akibat diskriminasi yang diperoleh dari kebijakan pemerintah setempat tetapi juga dari kelompok atau etnis lainnya. Presiden Thein Sein pernah menyarankan bahwa satu-satunya solusi terkait masalah Muslim Rohingya ini adalah dengan cara mendeportasi mereka. Kenyataannya sampai sekarang belum ada satu negara yang benar-benar memberikan hak kewarganegaraan terhadap mereka. Penduduk Muslim Rohingya pun masih dianggap sebagai kelompok etnis yang tidak berkewarganegaraan.

Tidak seperti golongan etnis minoritas lainnya yang setidaknya diakui kewarganegaraannya oleh rezim BurmaMyanmar, etnis Muslim Rohingya ini dianggap sebagai penduduk sementara dan tidak mendapat hak kewarganegaraan secara penuh. Sayangnya demokrasi baru yang telah diusung juga tidak membawa perubahan signifikan bagi mereka. Kebijakan maupun perlakuan diskriminatif yang selama ini diterima oleh warga Muslim Rohingya akhirnya menimbulkan respons atau sikap yang ditunjukkan.

Ada sebuah kepercayaan diantara mereka yang menyatakan bahwa Rohingya bukanlah termasuk Burmese (warga BurmaMyanmar), tetapi "Bengali" yang berasal dari Bangladesh atau manapun. Presiden Thein Sein sendiri pernah menyatakan bahwa satu- satunya solusi bagi etnis tersebut adalah mendeportasi mereka semua. Tidak ada negara manapun yang menerima mereka. Tidak heran jika akhirnya mereka tidak menjadi warga negara yang diakui secara legal dimanapun (Economist.com, 20 Oktober 2012). Permasalahan terkait warga negara inilah yang dianggap sebagai pemicu utama terjadinya berbagai konflik yang menimpa etnis Muslim Rohingya. Karena hal inilah, maka etnis Muslim Rohingya sering dijadikan objek diskriminasi.

Beberapa tulisan menyatakan bahwa etnis Muslim Rohingya juga pernah melakukan perlawanan. Respons pertama yang ditunjukkan adalah dibentuknya semacam tentara "Mujahid" yaitu pada masa pemerintahan Junta Militer. Pemberontakan yang dilakukan oleh etnis Muslim Rohingya bukanlah satu-satunya respons yang dilakukan. Selama rentang waktu 64 tahun semenjak Burma-Myanmar merdeka, warga Muslim Rohingya memiliki respons yang berbeda-beda. Berbagai perlawanan baik secara langsung atau tidak ditunjukkan etnis ini.Hal ini dikarenakan Burma-Myanmar yang sekarang dalam masa transisi demokrasi masih menunjukkan sikap yang diskriminatif. Terbukti dengan sikap pemerintah BurmaMyanmar yang tidak memihak bahkan terkesan membiarkan ketika konflik etnis berlangsung pada Juni dan Oktober 2012. Lebih lanjut pola respons yang dilakukan oleh etnis Muslim Rohingya bisa dikatakan memiliki perbedaan, baik dari masa periode sebelumnya yaitu periode Junta. Adapun dalam penulisan penelitian ini, penulis menggunakan metode kualitatif dengan studi literatur untuk mengumpulkan data serta analisis data bersifat induktif sebagai teknik analisisnya.

\section{Kebijakan Diskriminatif Pemerintah Burma-Myanmar}

Terdapat sekitar 1,4 juta warga Muslim Rohingya yang tersebar di berbagai penjuru dunia, dimana mayoritas mereka tinggal di Burma-Myanmar, diikuti dengan di Bangladesh dan Pakistan. Dahulu dikenal sebagai warga Muslim Arakan, Muslim Rohingya telah tinggal di negara bagian 
Rakhine selama lebih dari 500 tahun. Awalnya Muslim Rohingya hidup secara terpisah ketika jaman Burma-Myanmar dijajah oleh Inggris pada tahun 1780an, dilanjutkan dengan penjajahan Jepang pada Perang Dunia II dan akhirnya merdeka sehingga kekuasaan diambil alih oleh Jaman Junta Militer.

Sejak kemerdekaan Burma-Myanmar pada tahun 1948, Muslim Rohingya terus menerus menjadi etnis yang tertindas dan tidak diakui sebagai bagian dari 136 etnis yang diakui Burma-Myanmar. Padahal berdasarkan catatan sejarah, sebagai etnis mereka telah berdiam di Arakan sejak abad 7 masehi, jauh sebelum negara Burma-Myanmar berdiri pada tahun 1948. Etnis Rohingya selama beberapa dekade ini, utamanya sejak tahun 1940an selalu mengalami penindasan, pembunuhan, penyiksaan, perkosaan, pemiskinan, maupun diskriminasi baik oleh negara, pemerintah, maupun sesama penduduk yang berbeda etnis dan agama dengan mereka. Etnis Rohingya banyak yang tidak diakui kewarganegaraan Burma-Myanmar-nya. Juga, mereka tidak mendapatkan hak-hak selayaknya warga negara (Kurniawan, 2012).

Ancaman kekerasan terhadap etnis minoritas yang berbeda agama dengan etnis mayoritas yang beragama Buddha adalah akibat kebijakan diskriminatif yang diterapkan pemerintah. Pemerintah militer BurmaMyanmar menerapkan kebijakan asimilasi secara paksa dan tidak mengakui etnis tersebut sebagai bagian dari bangsa Burma-Myanmar dan menyatakan bahwa etnis tersebut bukan warga negara Burma-Myanmar. (Pramono, 2010: 47).

Berdasarkan laporan Amnesti Internasional, bentuk-bentuk kekejaman Junta Militer terhadap Muslim Rohingya antara lain:
1. Penolakan
pemberian kewarganegaraan.
2. Pembatasan untuk berpindah.
3. Pembatasan dalam kegiatan ekonomi.
4. Pembatasan dalam bidang pendidikan.
5. Pembunuhan, penahanan dan penyiksaan.

6. Pelecehan terhadap kaum wanita dan pembatasan pernikahan.

7. Kerusuhan anti Muslim Rohingya. Peneliti Amnesti Internasional, Benyamin Zawacki pada tahun 2012 menyatakan bahwa, "Sudah terlalu lama catatan mengenai Hak Asasi Manusia di Burma-Myanmar ternoda, dimana hal ini disebabkan tidak diberikannya hak kewarganegaraan terhadap etnis Muslim Rohingya dan juga diskriminasi terus-menerus yang diberikan terhadap mereka”. Pendapat Zawacki ini bukan tidak beralasan. Pemerintah militer Burma-Myanmar pada tahun 1988 melalui State Peace and Development Council (SPDC) menerapkan kebijakan Burmanisasi. SPDC berpendapat bahwa Burmanisasi tidak sama dengan komunalisasi karena etnis Burma adalah etnis mayoritas sedangkan budaya dan agama yang bukan berasal dari BurmaMyanmar adalah agama dan budaya asing.

Penduduk muslim dipandang sebagai orang asing karena mempraktekan cara hidup asing yang anti budaya Burma. Data terakhir yang penulis dapatkan pun, hingga saat ini tahun 2014 para pengungsi Rohingya masih belum mendapatkan hak penuh atas kewarganegaraannya. Tidak mengherankan pada Oktober 2014 banyak warga etnis Muslim Rohingya yang kembali menjadi boat people, yang meminta suaka ke Pulau Christmas, Australia.

Selain itu, terdapat perlakuan diskriminatif lain yang dilakukan pemerintah selain tidak mengakui kewarganegaraan etnis Muslim Rohingya, mereka juga tidak diakui hak-hak ekonomi, mengubah nama-nama tempat bersejarah Islam dan menyatakan bahwa etnis Muslim Rohingya adalah etnis Bengali. Motivasi utama pemerintah melakukan penindasan terhadap etnis Muslim Rohingya adalah untuk mencegah etnis Muslim Rohingya yang telah mengungsi kembali ke Burma-Myanmar (Levinson, 1994: 171). 


\section{Perlawanan Etnis Muslim Rohingya Zaman Junta Militer}

Terkait kebijakan maupun perlakuan diskriminatif yang didapat, pemberontakan bisa dikatakan merupakan respons pertama yang dilakukan oleh etnis Muslim Rohingya. Keadaan ini diakibatkan salah satunya ketika masa pendudukan Inggris. Pada era kolonial pendudukan Inggris kepada Burma, tidak ada pembagian wilayah yang jelas mengenai batasbatas territorial. Selain itu, keberpihakan Inggris kepada etnis Burma membuat etnis ini terkesan menjadi pemegang kuasa penuh atas wilayah Burma-Myanmar. Ditambah kudeta yang dilakukan oleh Ne Win pada tahun 1962. Kekuasaan Ne Win selaku pemimpin Union Revolutionary Council (URC) membuat ideologi negara Burma-Myanmar menjadi Sosialis.

Pergerakan yang terjadi di BurmaMyanmar dari krisis politik menjadi respons terhadap otoritarian di akhir tahun 1950 merefleksikan adanya ketidakseimbangan antara institusi sipil dan militer. Pada tahun 1956, terdapat gerakan yang akhirnya membentuk citra bahwa pemerintahan $\mathrm{U} \mathrm{Nu}$ adalah pemerintahan yang korup, sehingga membuat AFPFL (Anti-Fascist People's Freedom League) menjadi terpecah belah. Krisis pemerintahan $\mathrm{U}$ Nu yang terjadi pada tahun 1958 adalah ketika ia mencoba membuat AFPFL bersatu menjadi partai. Ketika didalam partai terjadi perpecahan, $\mathrm{U} \mathrm{Nu}$ mundur dari jabatannya sebagai Perdana Menteri dan memberikan kekuasaannya kepada Jendral Ne Win, hal ini membuat pemerintahan militer yang memegang kuasa, diikuti dengan kebijakan $\mathrm{Ne}$ Win yang merefleksikan Tatmadaw (Smith, 1999 dalam Bodreau, 2004: 49).

Setelah pemilu tahun 1960, bisa dikatakan inilah periode dimana banyaknya pemberontakan dimulai. Salah satu faktornya adalah ketika pemerintah membuat undangundang dan menjadikan Burma-Myanmar sebagai negara Buddha pada tahun 1962. Karena hal itulah maka muncul berbagai pemberontakan etnis dan menjadi agenda yang terus dipantau pemerintah. Pada tahun 1980an dan 1990an, terdapat sekitar empat puluh kelompok etnis yang memberontak. Setelah State Law and Order Restoration Council (SLORC) memiliki kekuasaannya di tahun 1988, beberapa dari kelompok pemberontak tersebut memilih untuk melakukan gencatan senjata.

Respons kedua yang dilakukan oleh etnis Muslim Rohingya adalah mengenai migrasi. Masalah migrasi ini bisa dikatakan paling terdengar dan diberitakan. Adapun isu yang paling berkembang mengenai warga Muslim Rohingya ini salah satunya adalah pengungsi yang terdapat di perbatasan Bangladesh. Hal ini yang membuat mereka dikatakan stateless.Mereka tidak diakui oleh pemerintah Burma-Myanmar (terutama semenjak Perjanjian Panglong pada tahun 1974) sebagai kelompok minoritas atau 'ras' yang diakui oleh negara. Mereka tidak memiliki hak sebagai warga negara dan bahkan mereka tidak bisa keluar dari kampungnya dengan legal. ${ }^{1}$

Dikarenakan tidak adanya pengakuan yang legal terkait warga negara maka warga Muslim Rohingya mulai melakukan migrasi demi mendapatkan hak politik di negara lain. Sekitar puluhan ribu warga Muslim Rohingya bermigrasi ke Malaysia melalui jalur laut, yang sejatinya adalah negara berpenduduk Muslim, tetapi status mereka tetap ambigu. Begitupun dengan Thailand yang juga akhirnya mengembalikan mereka ke laut-yang berujung menjadi manusia perahu atau boat people. Adapun pada tahun 1978, polisi Burma-Myanmar dan tentara melakukan tindakan yang membuat lebih dari 200.000 warga Muslim Rohingya bermigrasi ke Bangladesh atau disebut dengan Operasi Naga Min (ONM).

Melalui operasi itu, militer BurmaMyanmar melakukan pengusiran dan aksi kekerasan terhadap etnis Rohingya di Arakan. Lebih dari 1700 Muslim Rohingya yang tidak bisa menunjukkan kartu identitas dibunuh.

${ }^{1}$ Mereka tidak memiliki kebebasan untuk keluar masuk kampung atau daerah lainnya selain wilayah Arakan. 
Tidak sedikit yang diperkosa dan mengalami tindak kekerasan lainnya. Tidak kurang dari 200.000 Muslim Rohingya mengungsi ke Bangladesh. Di tempat yang terakhir ini, lebih dari 10.000 orang meninggal dunia karena kelaparan dan wabah penyakit (Danish Immigration Service, 2011: 8). Human Rights Watch (2009: 6) menyebut peristiwa ini sebagai "a murderous ethnic cleansing". Sebagian dipulangkan kembali di bawah pengawasan PBB. Kejadian yang sama pun berulang pada tahun 1991-1992, dan lagi-lagi ada sekitar 10.000-15.000 di repatriasi oleh $\mathrm{PBB}$, walaupun masih banyak yang tinggal di pengasingan.

\section{Zaman Transisi Demokrasi}

Pada masa transisi demokrasi, migrasi yang dilakukan oleh warga Muslim Rohingya bisa dikatakan "gelombang kedua". Hal ini dikarenakan migrasi dilakukan pasca pemilihan umum tahun 2007 dimana Thein Sein menjadi Perdana Menteri. Thein Sein sendiri dianggap sebagai seorang yang moderat dan juga reformis. Karena hal inilah maka ketika Thein Sein dilantik, dimulailah masa yang dianggap sebagai masa transisi demokrasi bagi Burma-Myanmar.

Setiap tahun, ribuan warga Muslim Rohingya yang tidak memiliki kewarganegaraan mendapatkan kekerasan dan represi di negara bagian Arakan dan tidak dapat bepergian di wilayah lain BurmaMyanmar-yang akhirnya membuat mereka memilih jalur laut dan berbahaya demi memperoleh hidup yang lebih banyak di Bangladesh, Thailand dan Malaysia. Tidak jarang akhirnya mereka mendapatkan kekerasan atau eksploitasi oleh para pedagang manusia, dikembalikan lagi ke laut dan malah menjadi tahanan di negeri-negeri asing karena tidak memiliki dokumen yang resmi (Human Rights Watch, 2009 dalam Humah Rights Watcs, 2012: 17).

Selain permasalahan mengenai migrasi, perdebatan terkait asal usul warga Muslim Rohingya menjadi salah satu faktor dalam membentuk wacana terkait etnis ini. Pada awal masa pemerintahan militer, mereka mengklaim bahwa warga Muslim Rohingya merupakan migran ilegal dan karenanya mereka tidak mendapatkan kewarganegaraan. Catatan mengenai migrasi yang mulai pada awal abad ke 19 yaitu pada masa penjajahan sendiri belum jelas. Kenyataan ini diperparah dengan adanya fusi warga turunan India dan Burma-Myanmar yang akhirnya menimbulkan eksodus besar-besaran.

Otoritas Burma-Myanmar juga menemukan adanya pelatihan militer di perbatasan Bangladesh, seperti yang dilaporkan intelijen Burma-Myanmar. Karena anggapan tersebutlah maka etnis Muslim Rohingya mendapat perlakuan yang paling melanggar HAM, disebabkan wacana teroris Mujahid. Anggapan buruk mengenai warga Muslim Rohingya juga berujung kepada isu identitas. Pada Agustus 2008, pemerintah mengeluarkan kartu identitas kepada 37.000 warga Muslim Rohingya yang pada tahap pertama diharapkan akan memberikan kepastian status (Steinberg, 2010: 109). Tetapi sayangnya hal ini belum bisa terwujud dengan baik disebabkan masih adanya sentimen kuat terkait identitas mereka.

Kekerasan yang terjadi pada warga Muslim Rohingya bukanlah hal yang baru. Ada tradisi yang membuat rumor negatif semakin berkembang-yang nantinya membuat mereka tidak mendapatkan hak kewarganegaraan secara penuh. Pendapat yang paling banyak dilontarkan oleh warga Bamar/Rakhine adalah bahwa mereka migran ilegal, sehingga banyak dari mereka tidak mendapatkan KTP atau NRC (National Registration Cards). Faktanya, banyak dari mereka yang memiliki NRC, tetapi tidak berlaku karena kebanyakan dari mereka disita sebelum melewati perbatasan, karena hal itulah maka mereka sering dianggap migrant ilegal.

Pemerintah Burma-Myanmar menawarkan solusi kewarganegaraan dengan syarat yang mendapat adalah keluarga yang minimal telah dua generasi lahir dan tinggal di Burma-Myanmar dan dikelompokkan kedalam etnis Bengali. Dikarenakan merasa bukanlah Bengali, warga Muslim Rohingya ini lebih memilih untuk tetap mempertahankan identitasnya. Kebijakan kewarganegaraan seyogyanya merepresentaasikan keunikan Burma-Myanmar sebagai negara yang multietnis, bukan sebaliknya. 
Faktor-faktor Pendukung Terjadinya Perlawanan

Faktor Internal

Faktor internal dalam sebuah perlawanan dapat meliputi beberapa hal. Salah satunya adalah terkait dengan sistem atau pemerintahan yang tengah berlangsung. Hal ini dibuktikan dengan adanya perbedaan pola tindakan yang telah dilakukan. Pada masa jaman junta militer bisa dilihat adanya pola yang lebih kuat dalam menjawab kebijakan yang telah dikeluarkan oleh pemerintah. Salah satunya adalah pemberontakan. Adapun kebijakan yang melatar belakangi hal ini salah satunya adalah Operasi Naga Min.

Azizah (2006: 99) menulis bahwa pada tahun 1978, pemerintah Burma melancarkan operasi militer untuk mengusir warga Muslim Rohingya dari Arakan. Mereka dianggap sebagai komunitas ilegal di tanah kelahiran mereka sendiri. Operasi yang disebut dengan nama Operasi Naga Min (Dragon King Operation/ Operasi Raja Naga) ini telah memaksa 200.000 Muslim Rohingya mengungsi ke negara Bangladesh untuk melarikan diri dari penganiayaan (Selth, 2003: 12). Padahal, saat itu jumlah penduduk Muslim Rohingya yang bermukim di Bangladesh sudah mencapai 156.630 orang (Tha, 2006). Operasi tersebut meliputi relokasi paksa warga Muslim disertai pemerkosaan, pembunuhan, dan penggusuran masjid (Selth, 2003: 12).

Selain melakukan migrasi, etnis Muslim Rohingya juga sempat melakukan pemberontakan. Pemberontakan yang terjadi menurut Ted Robert Gurr, yang dikuti oleh Riza Sihbudi (2000: 192) menyatakan ada tiga penyebab terjadinya pemberontakan. Pertama, karena secara psikologis masyarakat tertentu mengalami tekanan. Pada saat tekanan tersebut mencapai tingkat yang tak dapat ditahan lagi, maka akan timbul perlawanan atau pemberontakan. Peristiwa tersebut akan cepat berkembang jika ada tokoh dari masyarakat yang tertindas turut mendukung bahkan menjadi pemimpin perlawanan tersebut. Karena hal inilah warga
Muslim Rohingya meminta otonomi atas wilayah Arakan Utara dari warga Buddha atau Rakhine yang mayoritas mendiami Arakan Selatan. Kedua, karena perbedaan kelas yang tajam, sehingga menimbulkan kecemburuan sosial atau bahkan frustasi sosial di kalangan yang menderita yang jika tak terbendung lagi maka akan menimbulkan pemberontakan. Ketiga, karena rasa curiga akibat faktor suku atau agama dari pihak minoritas terhadap kaum mayoritas yang mendominasi.

Terkait dengan perlawanan yang dilakukan warga Muslim Rohingya yaitu pemberontakan yang dilakukan pada tahun 1988 dan mulai lagi dua dekade berikutnya, gerakan ini tidak bisa dikarenakan dari faktor internal warga Muslim Rohingya saja. Dalam tubuh internal warga Muslim Rohingya, pemberontakan dilakukan demi mendapatkan otonomi di wilayah Arakan Utara serta kejelasan atas hak hidup mereka. Terlepas dari berbagai wacana yang menyebutkan warga Muslim Rohingya disokong oleh pihak asing. ${ }^{2}$ Pada saat itu juga bisa dikatakan bahwa adanya keinginan yang kuat dari warga Muslim Rohingya untuk turut serta dalam pemberontakan dengan harapan pemerintah Burma-Myanmar dapat mengabulkan permintaan mereka.

Adapun interaksi sosial antar etnis yang terjadi malah membuat gerakan warga Muslim Rohingya saat itu semakin terbantu. Otoritarian yang dibentuk pemerintah BurmaMyanmar secara tidak langsung membuat seluruh elemen bersatu demi melancarkan kepentingannya masing-masing. Baik dari organisasi mahasiswa hingga terbentuknya kelompok pemberontak Karen, Kachin maupun Shan.

Interaksi sosial dalam negeri juga tidak lepas dari pergolakan kawasan Asia Tenggara kala itu yang dilanda krisis ekonomi maupun politik. Terbukti dari adanya Perang Dingin yang membuat kawasan Asia Tenggara dilanda dua kubu paham ideologi yaitu komunis dan liberal. Pemerintahan Ne Win yang cenderung sosialis membuat beberapa

2Pada masa rezim Ne Win memang keadaan negara dipenuhi oleh berbagai pemberontakan. 
kalangan-atau etnis merasa paham tersebut tidak pas dengan mereka. Karena dengan sosialis Buddha 3 , Ne Win menyebarkan paham fasisnya sehingga etnis non Buddha merasa tersingkir dan terdiskriminasi, sehingga pemberontakan dirasa merupakan salah satu resistensi yang bisa dilakukan. Warga Muslim Rohingya kala itu juga menjadi 'kuat' karena keadaan yang memang mendukung.

Selain itu, kebijakan lain yang mendukung terjadinya perlawanan adalah Hak Kewarganegaraan yang dikeluarkan pemerintah Burma-Myanmar pada tahun 1982. Sihbudi (2000: 52) seperti yang dikutip Azizah (2006: 100) menulis tidak lama setelah operasi Naga Min berlangsung, pada tahun 1982, penguasa militer Burma-Myanmar mengeluarkan sebuah dekrit tentang UndangUndang Kewarganegaraan Burma-Myanmar. Di dalam undang-undang tersebut, warga Muslim Rohingya dicoret hak kewarganegaraannya dan mereka menjadi tidak mempunyai negara (stateless) (Sihbudi, 2000: 89). Atas dasar hal tersebut, maka $\mathrm{Ne}$ Win yang menjabat Presiden kala itu menyatakan bahwa warga Muslim Rohingya adalah rakyat tanpa negara (people without state).

\section{Faktor Eksternal}

Berbicara mengenai perlawanan etnis Muslim Rohingya tentu tidak terlepas dari faktor eksternalnya. Faktor eksternal yang dimaksud salah satunya adalah bantuan dari pihak asing atau yang diluar wilayah Burma-Myanmar. Bukan hal baru ketika membahas mengenai pemberontakan yang sempat dilakukan umat Muslim Rohingya. Dugaan adanya pihak asing yang terlibat seperti jaringan Al-Qaeda atau Taliban membuat umat Muslim Rohingya terkesan sangat terbantu-mengingat mereka juga beragama Islam. Sehingga pemberontakan yang kala itu dilakukan tidak hanya demi kepentingan politik tetapi juga agama. Hal ini terlihat ketika kepentingan yang mereka usung dimana keinginan untuk

3Secara tidak langsung Ne Win mempraktekkan Sosialis Buddha, yang berarti membuat Buddha sebagai agama mayoritas dan memegang kekuasaan tertinggi. Bagi etnis membentuk daerah otonom muslim, yaitu di Arakan.

Perang Dingin merupakan salah satu faktor yang signifikan mengingat BurmaMyanmar yang mulai menjadikan negaranya sebagai negara Sosialis dan termasuk negara yang anti-komunis membuat hal tersebut sebagai alat. Alat yang dimaksud adalah penggunaan kekuasaan dengan sewenangwenang dan dapat dilihat dengan represi yang dilakukan di negara bagian tertentu (Bodreau, 2004: 8). Dengan jargon hanya etnis Burma yang memiliki hak sebagai warga negara asli Burma-Myanmar.

Pada akhirnya hal ini memunculkan spekulasi bahwa masalah terkait warga Muslim Rohingya ini bukan semata konflik sosial tapi juga agama. Memang tidak bisa dikatakan hal ini mutlak tetapi dengan adanya anggapan bahwa "Muslim adalah Teroris" bisa jadi hal tersebut memang benar. Anggapan dengan babak baru demokrasi ini juga berdampak pada dua hal. Pertama, etnis Rakhine semakin mengopresi warga Muslim Rohingya. Mereka menganggap dengan dibukanya keran demokrasi maka warga Buddha Rakhine bisa merebut kembali wilayah Arakan yang selama ini didominasi warga Muslim Rohingya. Selain itu, tindakan semena-mena seperti pembakaran masjid, rumah hingga disinyalir genosida membuat pemerintah tidak bisa berbuat apa-apa. Pemerintah sendiri secara tidak langsung juga mendukung hal ini. Kedua, warga Muslim Rohingya menjadi sedikit berani dalam mempertahankan identitas mereka. Dengan tetap menggunakan dialek Rohingya dan menolak dikatakan Bengali, warga Muslim Rohingya dinilai kuat mempertahankan identitas budayanya.

Di Burma-Myanmar, lima persen dari populasi warganya beragama Muslim.mayoritas mereka telah tinggal di negara tersebut selama berabad-abad. Padahal dengan permasalahn warga negara etnis Muslim Rohingya, Burma-Myanmar secara tidak langsung menolak prinsip-prinsip

lain yang tidak beragama Buddha, dianggap sebagai 'warga kelas dua'. 
demokrasi yang coba mereka usung. Hal ini tidak terlepas dari zaman periode Junta, dimana ketika mereka memerintah BurmaMyanmar, kewarganegaraan didasarkan dengan agama yang dianut.

Terkait dengan masa demokrasi baru yang terjadi di Burma-Myanmar dan penegakan nilai-nilai universal HAM, hal ini malah tidak membawa perubahan yang baik. Memang media swasta sudah mulai diperbolehkan. Tetapi kenyataannya, eskalasi konflik antar etnis yang meningkat juga tidak bisa diabaikan. Dengan anggapan adanya demokrasi , setiap etnis merasa mereka dapat berlaku sebebas bebasnya. Walaupun etnis Burma masih mendominasi dan juga mendiskriminasi, hal ini tidak menutup kemungkinan adanya represi antar satu etnis dengan lainnya. Terbukti dengan konflik komunal yang terjadi bulan Juni dan Oktober lalu.

\section{Etnis Muslim Rohingya dan Perlawanannya}

Pembicaraan mengenai perlawanan yang dilakukan oleh warga Muslim Rohingya memang tidak terlalu terdengar. Selama ini media lebih menyoroti kepada perlakuan diskriminatif yang diterima ketimbang perlawanan apa yang telah mereka lakukan. Permasalahan mengenai perlawanan yang dilakukan oleh warga Muslim Rohingya bisa dikatakan termasuk sulit dalam memetakannya. Karena tidak adanya indikator atau perlawanan yang signifikan. Sehingga hal tersebut sering dianggap bukanlah perlawanan atau pergerakan yang mutlak secara konsep. Tetapi disini penulis melihat bahwa berbagai tindakan maupun aksi yang dilakukan oleh warga Muslim Rohingya merupakan bentuk jawaban atas perlakuan diskriminatif yang mereka alami.

Salah satu penyebab terdapat perlawanan yang dilakukan adalah adanya "keakuan" didalam etnis tersebut. Situasi negara Burma-Myanmar yang heterogen membuat heterogenitas ini menjadi suatu yang solid. Habermas menyatakan heterogenitas ini melahirkan pertanyaan tentang kesatuan proses pembentukan-diri, yaitu hubungan antara berbagai media yang berbeda. Bahasa, sebagai sebuah warisan budaya, merupakan prasyarat bagi interaksi moral, "karena hanya makna yang konstan dan benar secara intersubjektif yang diambil dari warisan inilah yang memungkinkan adanya orientasi terhadap resiprositas, artinya harapan adanya perilaku yang saling melengkapi (komplementer) (McCarthy, 2011: 37-38).

Situasi pemerintahan atau sistem yang sedang terjadi di Burma-Myanmar juga memiliki pengaruh. Terdapatnya perbedaan resistensi pada saat rezim Junta dan masa transisi demokrasi menjelaskan bahwa sistem politik juga berperan. Ketika berbicara mengenai pemberontakan, hal tersebut terjadi saat Burma-Myanmar dipimpin oleh rezim Junta. Kelompok-kelompok saat itu termasuk Muslim Rohingya menginginkan adanya otonomi khusus terkait wilayah mereka. Hal ini juga diamini oleh etnis lain seperti Karen, Kachin dan Shan. Sedangkan ketika rezim junta jatuh, terdapat perbedaan perlawanan yang terkait dengan agenda yang ingin dicapai. Maka timbulah kelompok-kelompok yang lebih memilih untuk bermigrasi atau tetap tinggal dengan menjadi pengungsi di negaranya sendiri karena sudah tidak ada lagi pihak-pihak yang mendukung mereka dan kepentingan yang ingin dicapai juga berbeda, seperti saat ini, lebih kepada hak kewarganegaraan.

Dengan adanya kepemilikan sebuah identitas yang solid, maka timbulah berbagai gerakan yang sifatnya kolektif. Perlawanan yang dilakukan oleh warga Muslim Rohingya ini terkesan tidak hanya mengandalkan isu seperti kelas, ras tetapi lebih kepada kebudayaan mereka. Ini terkait dengan fenomena yang telah terjadi semenjak dua puluh tahun lalu dimana konflik sosial yang ada tidak hanya disebabkan persoalan politik tapi kepada tantangan kebudayaan sebagai bentuk dominasi baru. Dimensi-dimensi yang krusial dalam kehidupan sehari-hari (waktu, lahan, hubungan interpersonal, individu dan identitas kelompok) turut terlibat dalam konflik ini, dan timbulnya aktor-aktor baru yang menuntut otonomi atas hidup mereka (Melucci, 1995 dalam Johnston \& Klandermans, 1995: 41). 
Memang sejauh ini belum ada data pasti mengenai jumlah warga Muslim Rohingya, tetapi beberapa laporan menyebutkan terdapat sekitar 1,2 juta warga Muslim Rohingya. Dengan persebaran 800.00o di Burma-Myanmar (125.000 orang menjadi pengungsi) dan sisanya tersebar di berbagai belahan dunia. Ada yang berhasil mendapat suaka politik tetapi tidak sedikit yang akhirnya menjadi boat people-manusia perahu. Kemudian memunculkan anggapan mengapa solidaritas warga Muslim Rohingya tidak bisa efektif juga dikarenakan tidak adanya akses yang memadai bagi warga Muslim Rohingya yang ada di BurmaMyanmar. Laporan Human Rights Watch menyebutkan mayoritas warga Muslim Rohingya hidup dibawah garis kemiskinan dan mereka juga tidak mendapat pendidikan yang layak. Hal ini tidak terlepas dari peran pemerintah.

Selain itu, pemberian status kewarganegaraan bagi 800.000 warga Muslim Rohingya akan membantu Burma-Myanmar memiliki kebebasan sipil dan politik. Dukungan para biksu Buddha juga seharusnya dapat membantu mendorong warga lainnya untuk menciptakan perubahan. Agama Buddha dianut hampir $85 \%$ dari total keseluruhan penduduk Burma-Myanmar. Jika para biksu Buddha secara lantang mendukung kewarganegaraan untuk warga Muslim Rohingya, maka permasalahan kewarganegaraan kelompok minoritas tersebut bisa menimbulkan jalan keluar.

Etnis Muslim Rohingya pada kenyataannya saat ini memang masih belum memiliki kejelasan dalam status kewarganegaraannya tetapi bisa dikatakan bahwa perlawanan yang dilakukan saat ini lebih kepada adanya korelasi antara faktor internal dan eksternalnya. Adanya konflik komunal serta perhatian dunia yang mulai secara spesifik tertuju kepada BurmaMyanmar membuat kedua faktor ini sulit dipisahkan satu sama lain. Terkait faktor internal, permasalahan Muslim Rohingya ini terkesan sulit diselesaikan. Mengingat bahwa tidak hanya etnis mayoritas Barma tetapi juga etnis lain merasa etnis Muslim Rohingya merupakan sebuah masalah. Sedangkan terkait dengan faktor eksternal, dengan terpilihnya Aung San Suu Kyi sebagai salah satu anggota parlemen, membuat dunia berharap penuh akan terciptanya HAM yang baik di Burma-Myanmar. Walaupun hal tersebut tidak menjadi jaminan mengingat Suu Kyi tidak terlalu berkomentar masalah etnis Muslim Rohingya. Tetapi, bagi warga Muslim Rohingya, dengan tertujunya perhatian dunia terhadap permasalahan mereka, membuat etnis ini memilih cara sendiri dalam merespons perlakuan diskriminatif yang didapat yang mana akhirnya berkenaan dengan HAM.

\section{Penutup}

Etnis Muslim Rohingya merupakan salah satu etnis minoritas yang terdiskriminasi di BurmaMyanmar. Selama ini pemberitaan yang ada mengenai etnis ini lebih kepada penderitaan apa saja yang telah mereka dapatkan, bukan perlawanan atau respons apa yang mereka lakukan. Memang etnis ini merupakan etnis yang dianggap PBB sebagai etnis yang paling teraniaya. Pada kenyataannya, dari semenjak kemerdekaan Burma-Myanmar pada tahun 1948, setidaknya etnis ini juga melakukan beberapa perlawanan. Perlawanan yang dilakukan etnis Muslim Rohingya ini antara lain melakukan pemberontakan, migrasi hingga penolakan identitas dengan disebut sebagai etnis Bengali. Perlawanan yang dilakukan oleh warga Muslim Rohingya ini bisa dibagi berdasarkan dua periode yaitu pada masa pemerintahan Junta Militer dan Masa Transisi Demokrasi.

Pada periode yang pertama yaitu pada masa pro demokrasi dapat dilihat perlawanan yang dilakukan lebih cenderung politis, bersifat fisik dan langsung. Contohnya dalam melakukan pemberontakan. Pemberontakan yang dilakukan ini sebenarnya bisa dikatakan bersifat kolektif karena pada masa Junta Militer, tidak hanya warga Muslim Rohingya yang angkat senjata tetapi juga beberapa etnis minoritas lain yang bahkan sampai sekarang seperti Shan, Kachin dan Karen.

Sedangkan terkait perlawanan berikutnya yaitu migrasi, warga Muslim Rohingya ini terbagi menjadi dua kelompok. Alasan kedua kelompok tersebut sebenarnya 
sama yaitu untuk mencari suaka politik di negara lain. Tetapi jika dilihat lebih jauh, migrasi yang dilakukan pada masa Junta Militer diakibatkan oleh adanya kebijakan seperti ONM ataupun Hukum Kewarganegaraan Burma-Myanmar tahun 1982 (BCL). Kelompok yang kedua yaitu pada masa Transisi Demokrasi lebih diakibatkan adanya konflik horizontal atau konflik etnis yang terjadi, yang bahkan disinyalir sebagai bentuk genosida baru.

Lanjut kepada periode yang kedua yaitu pada masa transisi demokrasi. Perlawanan yang dilakukan oleh warga Muslim Rohingya ini lebih bersifat tidak langsung seperti pertahanan identitas. Pada masa transisi demokrasi, Burma-Myanmar dianggap sudah mencoba lebih kooperatif terhadap hal-hal yang berkenaan dengan HAM sehingga terdapat kelompok yang mempertahankan identitasnya dimana ketika pemerintah Burma-Myanmar mencoba menawarkan tanda pengenal atau KTP dengan syarat mereka mau dimasukkan dalam kategori etnis Bengali, dan mereka menolak.

Selain itu dapat dilihat pula penyebab terjadinya perlawanan yang ada yaitu dari faktor internal dan juga faktor eksternal. Faktor internal sendiri baik pada masa junta militer dan transisi demokrasi sama-sama tidak lepas dari campur tangan pemerintah.Pada masa junta militer, pemerintahan masa itu merepresi tidak hanya etnis Muslim Rohingya tetapi seluruh etnis minoritas selain etnis Burma, sehingga kaum Muslim Rohingya beserta etnis minoritas lainnya melakukan perlawanan dengan cara pemberontakan. Begitupun alasan etnis Muslim Rohingya melakukan migrasi yang disebabkan oleh tindakan represif pemerintah Junta Militer. Sedangkan pada masa pro demokrasi, faktor internal antara lain konflik antar etnis. Memang disini campur tangan pemerintah tidak terlihat secara langsung. Tetapi, konflik Rakhine yang terjadi pada Juni 2012 dan Oktober 2012 mengindikasikan bahwa pemerintah melangenggakan terjadinya konflik sipil tersebut.

Adapun dari faktor eksternal, pada jaman junta militer disinyalir terdapat campur tangan asing terkait dengan pembentukan tentara-tentara pemberontak. Sedangkan ketika jaman transisi demokrasi, world order yang cenderung kepada penegakan nilai-nilai demokrasi maupun HAM. Hal ini juga yang diharapkan dunia internasional agar BurmaMyanmar merubah sistem politiknya.

Karena hal itulah maka dinamika perlawanan etnis Muslim Rohingya bisa dikatakan berbeda menurut periode maupun situasi dunia yang melatarbelakangi terjadinya perlawanan. Dengan kata lain, perlawanan yang dilakukan mencerminkan kepentingan apa yang mereka usung. Berbagai tindakan yang dilakukan baik dari pemberontakan sampai menolak dikatakan sebagai bagian dari etnis Bengali bisa dikatakan sebagai bagian dari agenda pertahanan identitas mereka. Mengingat tindakan kolektif yang dilakukan berdasarkan pada identitas diri mereka sendiri.

\section{Daftar Pustaka}

\section{Buku}

Azizah. (2006) Pemberontakan Sporadis Muslim Rohingya Pasca Kemerdekaan Burma 1948-1988. Jakarta: Universitas Indonesia.

Bodreau, V. (2004) Resisting Dictatorship: Repression and Protest in Southeast Asia. New York: Cambridge University Press.

Danish Immigration Service. (2011) Rohingya Refugees in Bangladesh and Thailand. Copenhagen: Danish Immigration Service.

Human Rights Watch. (2009) Perilous Plight: Burma's Rohingya Take to the Seas. USA: Human Rigths Watch.

. (2012) "The Government Could Have Stopped This": Sectarian Violence and Ensuing Abuses in Burma's Arakan State. USA: Human Rights Watch.

Levinson, D. (1994) Ethnic Relations: A CrossCultural Encyclopedia. Santa Barbara: ABC-CLIO Inc.

Melucci, A. (1995) "The Process of Collective Identity" dalam Johnston, $\mathrm{H}$ \& Klandermans, B (eds). Social 
Movements and Culture. Minneapolis:

University of Minneapolis.

Selth, A. (2003) Burma's Muslims: Terrorists or Terrorised?. Canberra: Strategic and defence Studies Centre the Australian National University.

Sihbudi, R. dkk. (2000) Problematika Minoritas Muslim di Asia Tenggara: Kasus Moro, Pattani, dan Rohingya. Jakarta: PPW-LIPI.

Smith, M.. (1999) Burma: Insugency and The Politics of Ethnicity. New York: St. Martin Press.

Steinberg, D. (2010) Burma/Myanmar: What Everyone Needs to Know. New York: Oxford University Press.

Pramono, A. (2010) Peran UNHCR Dalam Menangani Pengungsi Myanmar Etnis Rohingya di Bangladesh (Periode 1978-2002). Jakarta: Universitas Indonesia.

\section{Artikel Online}

Burma Muslim. "Muslims in Burma" [Online], tersedia dalam <http://www.burmamuslims.org/> [Diakses pada 1 November 2012].

Economist.com. "Myanmar's Rohingyas: No help, Please, We're Buddhists" [Online], tersedia dalam <http://www.economist.com/news/a sia/21564909-when-offendingmuslim-world-seems-small-pricepay> [Diakses pada 20 Oktober 2012].

Kurniawan, Nanang. (2012) "Nasib Etnis Minoritas Rohingya”, dalam Pusat Informasi dan Advokasi RohingyaArakan (PIARA) [Online], tersedia dalam

<http://www.jprmijakbar.org/index. php/berita/berita-dunia-islam/133nasid-rohingya.html > [Diakses pada 28 Juli 2012].

Tha, KZyaw Zan. (2006). "Background of Rohingya Problem" [Online], tersedia dalam $<$ http://rakhapura.com/read.asp?id= 4\&a=scholarscolumn $>$ [Diakses pada 12 Februari 2013]. 
